\title{
The Impact of Income Disparity on Social Conflicts
}

\author{
Didit Welly Udjianto, Joko Susanto*
}

Economic and Business Faculty, UPN "Veteran" Yogyakarta, Indonesia

Copyright $\bigcirc 2017$ by authors, all rights reserved. Authors agree that this article remains permanently open access under the terms of the Creative Commons Attribution License 4.0 International License

\begin{abstract}
In many cases, there is an irony when regional economic growth is high, but most of the population is poor due to the income disparity. The impacts of income disparities on social conflict are the main reasons for doing this research. The panel data regression analysis is used in this research. Therefore, the results show that an increase in income disparity will be followed by a rise in social conflict. Income disparities promote a lower middle group feels unfair and reflect their disappointment in a dysfunctional behavior that deviates from the rules. A group of people who mutually have dysfunctional behavior leads to social conflicts.
\end{abstract}

Keywords Impact, Income, Disparity, Social, Conflict

\section{Introduction}

The rapid regional economic growth has changed some cities in Yogyakarta Special Region and Central Java Province. Some of the areas that were originally a non-urban area have developed into an urban area. These changes are accompanied by a change of a socio-economic status, population number and an economic activity. The residents tend to move to the city and their occupations change from agriculture sector to the non-agricultural sector that covers several economic activities from informal sector to formal sector. An increase of economic activity indicates the city growth. Recently, there are some economic activities springing up along with the development of the cities.

The growth of the city has occurred by the infrastructure support. More economic growth needs more infrastructure support. However, major cities have some infrastructure such as terminals, highways, ports, airports and other public facilities. There is a tendency that cities with adequate infrastructure become new investment destinations. These cities tend to get a large additional investment than cities without adequate investment. The availability of infrastructure reduces the production cost so the product has a competitive advantage. The firm will attempt to build its plant in locations with an adequate infrastructure. There is a strong correlation between investment and location determination. Investments tend to be concentrated in a specifically-located place [1]. Usually, the factory is located near the market or the port.

The region that gets an additional investment will grow faster than the other region. The economic growth leads to a change in the region from a non-urban area into an urban area. In other words, an urban agglomeration has occurred. The agglomeration is characterized by a diversity of economic activity that increases in line with the city growth. The companies prefer to locate themselves in a larger city with its complete infrastructures such as toll roads, ports, and airports.

The infrastructure supports promote a city to have a diversity of economic activity that is more than economic activity in towns. The business and profession have sprung up along with the development of the city economic activities. Various business and profession have emerged in line with the city development. Indeed, each profession requires a certain skill. The workers in a firm consist of many kinds of workers such as the worker under a supervisor, supervisor, administrator, accountant, secretaries, and manager. Therefore, the labor productivity is different based on their professions.

Pernia and Salas [2] find that labor productivity is associated with the wage rate so this rate is mainly determined based on productivity. The employer is only willing to offer higher wage rate to more productive workers. Higher skill workers receive a higher wage and vice versa. Therefore, disparities in labor productivity among their professions promote wage disparities among groups of workers. The wages disparity has occurred as the impact of disparity in workers' skill. Disparities in the workers' skills are a decisive factor of wage disparity [3].

Furthermore, the disparity has an impact on growth. There are two different theoretical views on the direction of disparity and growth relationship provided. These two approaches are called the classical approach and the modern paradigm [4]. The classical approach suggests that the accumulation of physical capital is the main factor that determines disparity. Dynan, Skinner, and Zeldes [5] suggest that saving rates increase with wealth and that wealthier people have a higher marginal propensity to save 
[5]. When resources are more concentrated among individuals, the aggregate investment in physical capital will be relatively higher, fostering economic growth [6]. Conversely, the modern paradigm focuses on the role of human capital accumulation rather than on investment in the physical capital [7]. Chingano [8] states that the negative relationship between inequality and growth might be driven by obstacles to human capital accumulation.

Like many other developing countries, Indonesia faces the problem of poverty, of unemployment, and of income inequality. The poverty, unemployment, and income inequality have declined after the development program has been implemented. Indonesia has achieved many signs of progress in reduction of poverty, unemployment, and income inequality. Economic growth in Indonesia has helped to reduce poverty and unemployment. The poverty rate fell from $19.87 \%$ in 2010 to $8.22 \%$ in 2015 . Meanwhile, the unemployment rate fell from $9.11 \%$ in 2010 to $6.18 \%$ in 2015. Furthermore, the income inequality has narrowed slightly in Indonesia, reflected by a declining Gini coefficient. This condition shows that the income inequality has decreased. However, the problem of income inequality still occurs in several provinces including in Yogyakarta Special Region and Central Java Province. The income distribution in Yogyakarta Special Region is the worst in Indonesia. The Gini coefficient of Yogyakarta Special Region in 2017 is 0.425 which is the highest value in Indonesia. Meanwhile, the Gini coefficient of Central Java Province is also still quite high, reaching 0.386 .

Due to the location of Yogyakarta Special Region flanked by Central Java Province, there is an economic unity between both provinces. The economic development in both provinces runs simultaneously. This economic relationship is supported by a rapid economy growing in Joglosemar district that includes the cities of Yogyakarta, Solo, and Semarang. Some cities located near Joglosemar districts such as Magelang, Salatiga, Semarang, Pekalongan, and Tegal are growing rapidly because of the adequate infrastructure.

The high economic growth is characterized by the growth of economic activities such as industry, trade, and services. A wide variety of economic activities leads to the emergence of various businesses and professions with the wage rate that differs from each other. The disparity in wage level indicates the income disparity. The income disparities will have an impact on social conflict because low-income community frequently feels unfair. The potential of social conflicts increases along with the development of cities in Yogyakarta Special Region and Central Java. Therefore, this study identifies the relationship between the income disparity and social conflict.

The remainder of the paper is organized as follows. Section 2 outlines the theoretical framework of income disparity and social conflict. Section 3 presents the data and the methodology used for estimation. Section 4 analyzes the impact of income disparity on social conflict. Then, Section 5 presents some conclusions.

\section{Income Disparity and Social Conflict}

Economic growth is the most powerful instrument for reducing poverty and improving the quality of life. Therefore, an economic growth will be followed by a poverty reduction. There are more goods and services offered to people in a country or region. An increase of consumption indicates a better social welfare. However, sometimes there is an irony when higher regional economic growth is accompanied by a lower quality of life, i.e. most of the population work in low-wage manufacturing industries. The low-wage job causes relative poverty and potentially has an impact on social problems.

Economically, social problems arise from an uneven income distribution as the impact of heterogeneity in resources ownership. The population consists of some society with various strata. There is a group of community members who have more resources than other people. In regard to economic growth, then, the problem is there are many goods and services that cannot be enjoyed by all members of the community equally. There are a small number of residents who experience the upper layer of goods and services produced by the economy, while the others just enjoy relatively small quantities. Indeed, not all residents enjoy higher economic growth. Heterogeneity ownership in resources causes not all members of the community able to participate in the production process. This means that there are some residents who did not participate in the production process, and so they do not get an income. Therefore, there is an income disparity among community members. Recently, the income disparity has become the most debated issues by the policymaker and has taken a lot of attention [9].

The income disparity has been widely discussed in the last two decades. Disparities in income arise from the concentration of physical investment and human capital accumulation. Indeed, in determining the location of investment, the investor seeks a competitive area. Economically, the most competitive region will include some cities which have good infrastructure and human resources. Jones and Romer [10] suggest that from a development perspective, infrastructure offers two benefits: 1) it raises productivity and reduces the cost of private production, and 2) it has a disproportionate effect on the incomes and welfare of the poor by reducing costs. Similarly, the availability of skilled human resources is able to furnish the availability of physical capital so that the combination of both factors leads to the efficient production process.

Moreover, in order to increase their production 
efficiency, the companies tend to offer higher wages which are more likely to attract and retain more productive workers [11]. Dube, Naidu, and Reich [12] find that higher wages lead to lower turnover, reducing the costs of hiring and training new workers. Although the firm pays a higher wage for a high-skill worker, they get the more productive workers which in turn will reduce the production cost. This means that the highly qualified workers and good infrastructure make the manufacturing process run efficiently. Goods and services can be produced at a lower cost so that the product has a high competitiveness. Furthermore, with a high competitiveness, a firm will get a larger market share.

Due to the good infrastructure, the companies prefer to locate themselves in the larger city. This means that urban agglomeration process has started. However, not all the citizen can take advantage arising from the agglomeration [13]. Some highly educated people can take advantage of the agglomeration. With their skills, they can get a job in the productive sectors and get a high income. On the other hand, there are some citizens who fail to take advantage of urban agglomeration. They are forced to work in the low-wage manufacture and therefore they cannot get an adequate income.

As a result of labor surplus problem, in Indonesia, there are many people who work in the low-wage manufacture sector. The excess of surplus labor makes the labor market be determined by labor demand. With wage efficiency considerations, the firm frequently determines the specifications of workers required. The firm wants to hire only skilled labors. These specifications make not all of the citizens able to meet the required specification. Oftentimes, there is a job position in an industry which is not filled in, meanwhile, there are some people who do not get the job.

Some people who do not get jobs will be unemployed or forced to work in the informal sector with a lower productivity and a lower wage. This condition causes a disparity income and leads to social problems. The low-income group cannot meet their needs, especially the secondary and tertiary needs so that they feel dissatisfied with government policies. Some research comparing different groups in different countries suggests that people in lower socio-economic groups in more equal countries do better than those in lower socio-economic groups in more unequal countries. They may even sometimes do better than people in higher socio-economic groups in more unequal countries [14].The social problems are higher in areas with high-income disparity as well [15].

Furthermore, the disparities in income make the low-income people feel unfair. The realization of the unfair assessment is reflected in dysfunctional behavior. The dysfunctional behavior refers to people action that deviates from the society standards. These behaviors do not follow the conventional social and moral rules of their society. Dysfunctional behaviors are often evaluated negatively and usually make a social problem. If this action continues, it will harm social welfare.

\section{Research Methods}

This study uses the raw data from the Statistics Indonesia. The use of raw data is intended to eliminate bias due to aggregation process. The data includes the wage rate, population growth, employment, and social conflicts. The scope of the study is the social economic condition from 2001 to 2013. The selection of the starting point in 2001 is because this is the starting point of regional autonomy that indicates a part of decentralization process. Then, the final point in 2013 is because this is the latest publication from the Statistics Indonesia. Based on the data availability, the scope of the research includes the socio-economic conditions in Yogyakarta, Solo, Salatiga, Magelang, Semarang, Pekalongan and Tegal. All of these cities are located in Yogyakarta Special Region and Central Java Province.

The variables are described as follows. 1) Social conflict is measured by a number of civil cases filled in Court Country, 2) The income disparity is the difference between the lowest wage (the city minimum wage) and the highest wage (manager wage), 3) Population growth is the percentage increase of the city population annually, 4) Employment growth is a percentage increase in the working population annually.

This study covers the social and economic conditions of cities in Yogyakarta Special Region and Central Java Province during 2001-2013. Thus, the research data are a panel data, which is the combination of cross-section and time series data. The panel data have several advantages compared to cross-section or time series data [13]. Panel analysis permits the researcher to study the dynamics of change with short time series. The combination of time series with cross-section can enhance the quality and quantity of data. Panel data analysis can provide a rich and powerful study of a set of people if one is willing to consider both space and time dimension of the data.

Meanwhile, to determine whether there is a long-run equilibrium relationship among variables in the model, Kao cointegration test is used. Furthermore, to determine whether the right model is the fixed or random effect model, Hausman test was used in this study. This research model is manifested in a dynamic regression model that covers a lag variable, both on the right-hand side or the left-hand side. To obtain a simple estimation model, the study applies reduction test and vector autoregressive (VAR) based on Akaike Information Criteria (AIC) ranging from the longest lag to the shortest lag. The AIC is superior to the other criteria under study in the case of a small sample [14]. The estimated regression model is written in the following equation.

$$
Y_{i, t}=\beta_{0}+\beta_{1} X_{1 i, t-j}+\beta_{2} X_{2 i . t-j}+\beta_{3} X_{3 i . t-j}+e_{i . t}
$$

Respectively $X_{1}$ is the income disparity (percent), $X_{2}$ is population growth (percent), $X_{3}$ is the employment growth (percent), and $Y$ is a social conflict (the case). 


\section{Results and Discussion}

\subsection{Results}

The Kao cointegration test results demonstrate its rejection of $H_{0}$ stating the absence of cointegration between variables in the model. The t-statistic of $-3,949$ with a $p$-value of 0,00 . The $p$-value is less than 0.05 and therefore statistically significant. This means that variables in this model have a long-run equilibrium relationship in line with economic theory. This model has a consistency or at least there is a one-way causality relationship among variables. Furthermore, based on the estimated VAR, the minimum AIC value occurs for the lag length is one year. It means that estimation VAR with lag one will be spared from the model specification errors and from the problem of degrees of freedom. Estimation VAR with a lag one is a parsimonious VAR.

In a panel data regression, there are two (2) basic models: fixed-effects model and the random-effects model. The Hausman test results show that the value of $m$ is greater than $x^{2}$ with a $95 \%$ degree of confidence, then this study chooses fixed effect model. Therefore, the analysis is carried out on the fixed-effects model. A fixed effects model is a statistical model in which the model parameters are fixed or non-random quantities.

Table 1. The Impact of Income Disparity on Social Conflict (Fixed Effects)

\begin{tabular}{cccc}
\hline Variable & Coefficient & $t$-statistic & $t$-table $(\alpha=5 \%)$ \\
\hline$C$ & -5.155 & -0.194 & -1.645 \\
Income Disparity & $0.043^{*}$ & 3.976 & 1.645 \\
Population growth & $4.605^{*}$ & 1.848 & 1.645 \\
Employment growth & 2.085 & 1.602 & 1.645
\end{tabular}

Dependent Variable: Social Conflict

Adjusted $\mathrm{R}^{2}=0,689 F=23,238$

*) significant at $(\alpha=5 \%)$.

Furthermore, through the reduction of the insignificant parameters, the reduction results show that the value of coefficient redundant $\mathrm{F}$ is smaller than a value of $\mathrm{F}$ table $(\alpha=5 \%)$ so this result is insignificant. This means that reduction model is the right model, so analysis will be done based on this model. The coefficient of determination $\left(\mathrm{R}^{2}\right)$ of 0.689 indicates that 68.9 percent of variations in social conflict can be explained by the variation in the dependent variables, while the remaining of 32.1 percent is explained by residuals. In line with the higher $\mathrm{R}^{2}$, the $\mathrm{F}$ value amounted to 23.238 is statistically significant. It shows that the independent variables jointly affect the social conflict.

\subsection{Discussion}

The regression coefficient of income disparity is 0.043 . This suggests that a one-million increase in income disparity will be followed by 43 cases rise in social conflicts (other variables in constant). Income disparity leads to a low-income group feeling unfair. The realization of the unfair assessment was the dysfunctional behavior. This means that the behavior of a group deviating from the rules or norms would lead to social conflict.

Dysfunctional behavior arises because citizens will compare the income received with the income of other citizens in the city. Income disparity causes some people feel unfair and tends to non-cooperative action towards government policies. Meanwhile, the success of the government development programs depends on the willingness of all citizens to work together. Development is the result of a cooperation of all citizens. Without community participation, the development program cannot be implemented properly. The non-cooperative citizen action inhibits the implementation of the government development programs and leads to a social problem.

Economically, the main problem of social conflict is the social-economic relation that leads to a seizure of resources ownership. The resource availability is very limited, but the citizen's need is not limited. Therefore, not all citizens get adequate resources. It means that there is an uneven income distribution. If the citizens have more resources, they can invest their resources in the economic sector and get returns on their investment. Then, their returns can be invested in another economic sector. In this way, they enjoy more returns. Meanwhile, if the citizens do not have adequate resources, they cannot invest and cannot get returns. This means that their resource is just enough for fulfilling their family consumption. Therefore, if this condition continues, there is a worse income distribution.

The worse income distribution is characterized by a high Gini coefficient. Recently, a higher Gini coefficient of Yogyakarta Special Region and Central Java Province indicates that there is a worse income distribution in both provinces. The uneven income distributions are regarded as a source of the social problem. The poor who do not have adequate resources will try to get an additional resource, while the rich also want to raise their wealth through investment. The limited resources available frequently make these groups compete with each other. The poor do some actions, for example, a demonstration to ask a higher wage and higher social benefit. The poor, especially workers, do a strike that harms the production process. However, they want to pressure the rich, especially employers, to increase the wage rate.

Conversely, the employers also want to press the wage rate in order to raise their profits. If the employers cannot raise their product price due to a tight competition, they want to minimize the production cost. The production cost covers some components such as a wage cost. For the employers, a wage is a cost, but for the workers, a wage is a source of revenue. Of course, if the wage rate cannot be determined by negotiation between workers and employers, this condition will threat the firm survival. If the condition occurred, both parties would become the losers. The workers will lose because they do not work and do not get 
an income to fulfill their family needs. Meanwhile, in Indonesia, there is no unemployment benefit so the idler does not get anything. On the other hand, the employers will lose because the production process stop and they cannot fulfill their order so that there is no revenue for them. The failure of wage rate negotiation also leads to a worse income distribution.

The income disparity makes cooperation among citizens difficult to be done. The people want a more equitable income distribution. This condition will be achieved if the income disparity decreases. So far, the income disparity has occurred because of the rapid infrastructure development but the lower middle class is unable to use it. The other cause is a capital problem. Due to the limited capital, there are some people who have the potential and capacity but they do not run their business. Therefore, the programs that can be done to reduce income disparity are done by increasing more equitable infrastructure development and community empowerment. This community empowerment program is done by providing access to capital and other assistance for people who have capacity but have a capital problem. If the low-income group is able to access infrastructure and obtain capital assistance, their productivity will increase. An increase in productivity will be followed by an increase in their income, and then it will reduce the income disparity.

Moreover, the regression's coefficient of population growth is 4,605 and it is significant. This means that a one-percent increase in population growth will be followed by an increase of social conflict by 4,605 cases. Unlike the developed country, Indonesia has a labor surplus problem that is characterized by labor supply which exceeds its demand. Indonesia population is the fourth largest in the world so that there are many people who seek a job, while labor demand is not as big as labor supply. Those who are not accommodated in the formal sector are forced to seek a job in informal sector with low wage rate or to be unemployed. The high population growth accompanied by a low employment creates a social problem. The higher number of working age population requires a higher employment. However, the higher employment will be created if there are many jobs that are offered to society members. However, a number of jobs offered to society depend on the economic growth. If the growth is low, there are no adequate jobs offered to society members.

The higher economic growth indicates that there is more production process. However, the production process requires some inputs, especially labors that used to manufacture the output. Higher economic growth brings higher labor demand. This means that there are more workers used to produce the output. The employment rate increases as a result of higher economic growth. An increase in economic growth is followed by a decrease of the unemployment rate and then leads to a decrease in social conflict. Therefore, the government must concern to the economic growth and issue some policies to encourage the attainment of the goal.

The economic growth depends on the availability of some resources, especially investment. Therefore, the government needs to issue a policy to increase investment both foreign and domestic investment. Recently, there are many obstacles to capital inflow such as poor infrastructure, bureaucracy and so forth. Good infrastructure attracts capital inflow because it lowers production cost. Meanwhile, along bureaucracy reduces the attractiveness of a region. The production cost will increase due to a long bureaucracy. Therefore, the government must simplify this long bureaucracy.

Furthermore, the regression coefficient of employment growth is not significant. This condition probably indicates a multicollinearity problem that often arises in a regression model. Multicollinearity is a phenomenon in which two or more predictor variables in multiple regression models are highly correlated, meaning that one can be linearly predicted from the others with a substantial degree of accuracy. Multicollinearity is reflected by a higher correlation between population growth and employment growth. The correlation is 0.334. Meanwhile, the correlation between income disparity population growth and employment growth, respectively, are only -0.153 and 0.101. If multicollinearity has occurred, the estimation of one variable's impact on the dependent variable while controlling for the others tend to be less precise.

\section{Conclusions}

Heterogeneity in resources ownership causes not all members of the community able to participate in the production process. Therefore, they do not get an adequate income, while other people participate fully and enjoy enough income. Indeed, income disparity is a consequence of heterogeneity in resources ownership. The low-income people feel unfair and reflect their disappointment in a dysfunctional behavior. Their behavior deviates from the established rules or norms. Therefore, an income disparity leads to a social conflict.

The local government can reduce income disparity by having more equitable infrastructure development and community empowerment. This community empowerment program is done by providing access to capital and other assistance for people who have capacity but have a capital problem. If the low-income group is able to access infrastructure and obtain capital assistance, their productivity will be increased. The increased productivity of this group will be followed by an increase in their income, and then it will reduce the income disparity. This community empowerment program cannot only rely on the regional government budget but also increase the contribution of companies through their corporate social responsibility. 


\section{REFERENCES}

[1] Lall, S., Shalizi, Z. and Deichmann, U. Agglomeration Economies and Productivity in Indian Industry, Journal of Development Economics, (2004); 73(2): 643-673.

[2] Pernia, E. M. and Salas J. M. I. Investment Climate, Productivity, and Regional Development in a Developing Country, Asian Development Review, (2006); 23(2 ): 70-89.

[3] Combes, P., Duranton. G, and Gobillon, L. Spatial Wage Disparities: Sorting Matters! Journal of Urban Economics,(2008); 63(2): 723-742.

[4] Galor, O. Income Distribution and the Process of Development, European Economic Review, (2000); 44(4-6): 706-712.

[5] Dynan, K. E., Skinner, J., and Zeldes, S. P. Do the Rich Save More? Journal of Political Economy, (2004); 112(2): 397-444.

[6] Barro, R., J. Inequality, and Growth in a Panel of Countries, Journal of Economic Growth; (2000) 5 (1): 5-32.

[7] Galor, O., and Moav, O. From Physical to Human Capital Accumulation: Inequality and the Process of Development, Review of Economic Studies, (2004); 71(4): 1001-1026.

[8] Cingano, F. Trends in Income Inequality and its Impact on Economic Growth, OECD Social, Employment and Migration Working Papers, 163. OECD Publishing, 2014.
[9] Dabla-Norris, E, Kochhar, K., Suphaphiphat, N., Ricka, F., and Tsounta, E. Causes and Consequences of Income Inequality: A Global Perspective, IMF Staff Discussion Note, 2015.

[10] Jones, C. and Romer, P. The New Kaldor Facts: Ideas, Institutions, Population, and Human Capital, American Economic Journal: Macroeconomics (2010); 2(1): 224-245.

[11] Dal Bo, E., Finan, F., and Rossi, M. Strengthening State Capabilities: The Role of Financial Incentives in the Call to Public Service, The Quarterly Journal of Economics, (2013); 128 (3): 1169-1218.

[12] Dube, A., Naidu, S., and Reich, M. The Economic Effects of a Citywide Minimum Wage. Industrial and Labor Relations Review, (2007); 60 (4): 522-43.

[13] Brown, W. M. Urban Productivity: Who Benefits from Agglomeration Economies? Research Paper No. 084, University of California Los Angeles, 2013

[14] Rowlingson, K. Does Income Inequality Cause Health and Social Problems? Working Paper, Joseph Rowntree Foundation, 2011.

[15] Wilkinson, R., and Pickett, K. The Spirit Level, Bloomsbury Press, New York, 2011.

[16] Baltagi, B. H. Econometric Analysis of Panel Data, John Wiley, and Sons. 2003.

[17] Liew, V. K-S. Which Lag Length Selection Criteria Should We Employ? Economics Bulletin, (2004); 3 (33):1-9. 